\title{
Argentinean Copper Concentrates: Structural Aspects and Thermal Behaviour
}

\author{
Vanesa Bazan $^{1 *}$, Elena Brandaleze ${ }^{2}$, Leandro Santini ${ }^{2}$, Pedro Sarquis ${ }^{3}$ \\ ${ }^{1}$ CONICET - Instituto de Investigaciones Mineras, Universidad Nacional de San Juan, San Juan, Argentina \\ ${ }^{2}$ Metallurgical Department and Technology and Materials Develop Center, DEYTEMA-Universidad Tecnológica \\ Nacional, Facultad Regional de San Nicolás, Colón, Argentina \\ ${ }^{3}$ Instituto de Investigaciones Mineras, Universidad Nacional de San Juan, San Juan, Argentina \\ Email: "bazan@unsj.edu.ar, ebrandaleze@frsn.utn.edu.ar, psarquis@unsj.edu.ar
}

Received July 4, 2013; revised August 5, 2013; accepted August 28, 2013

Copyright (C) 2013 Vanesa Bazan et al. This is an open access article distributed under the Creative Commons Attribution License, which permits unrestricted use, distribution, and reproduction in any medium, provided the original work is properly cited.

\begin{abstract}
In Argentina, there are many sources of copper concentrates. Some of them are currently in operation, while others are in the exploration stage. All copper concentrates produced are exported to other countries for copper refinement and to create various finished products. It is desirable that in the near future, these copper concentrates will be processed in an Argentinean industrial plant. The aim of this paper was to present the results of a characterisation study carried out on five different copper concentrate samples. The thermal decomposition of the copper concentrates was determined by differential thermal analysis and thermogravimetry (DTA TG). The information was correlated with the chemical composition and the mineralogical phases of the samples identified by X-ray diffraction. A melting test at temperatures of up to $1300^{\circ} \mathrm{C}$ was performed to complete the study of the concentrate's behaviour during heating. After the test, all of the samples were observed by light and electronic scanning microscopy to identify the different phases generated under high-temperature conditions.
\end{abstract}

Keywords: Copper Concentrates; Thermal Analysis; Pyrometallurgy; Mineral Phases

\section{Introduction}

The copper market is undoubtedly one of the most important metallic markets in the world. This statement is based on the significantly increased global demand for this metal and its alloys in recent years.

Argentina has large reserves of copper ores and constitutes a strong supplier of concentrates in our region [1-4]. The ores selected for this study contain between $0.5 \%-0.8 \%$ copper and are free of impurities such as $\mathrm{Sb}$, As, Te and Se. Currently, concentrates obtained by flotation operations are exported to other countries to produce final copper products such as wires, pipes and sheets [5]. It is important to promote the installation of a copper pyrometallurgy plant in our country to allow for the ability to process concentrates and create final products for Argentina's domestic market. Copper industrial processes include melting, conversion and refining operations [6]. To design the pyrometallurgy process, it is necessary to completely characterise the concentrates. Thus, it is necessary to obtain information about the current phases

${ }^{*}$ Corresponding author. that exist in concentrate particles and the type of transformations and reactions that occur under processing conditions [7].

Winkel et al. [8] described the importance of enhancing the knowledge about the high-temperature behaviour of copper iron sulphides, as well as the volatile impurities they contain. This information is essential to develop new processes of extractive metallurgy.

Thermal analysis techniques, such as differential thermal analysis (DTA) and thermogravimetry (TG), represent important tools to determine the concentrates' behaviour during the decomposition of copper iron sulphides and sulphur volatilisation rates [8-12].

In this paper, information regarding the thermal behaviour of five samples of Argentinean copper concentrates is presented. The results obtained by DTA and TG were correlated with information determined by X-ray diffraction (XRD) and a microscopy study. Structural analyses of the concentrate samples were performed after the melting tests. The test products were examined by electron microscopy (SEM), and the phases were identified by XRD. The authors describe the mechanisms, such 
as mass transport, which allow for the separation of metallic copper.

\section{Materials and Methods}

\subsection{Samples}

Five samples of copper concentrates obtained by Rougher flotation were selected for this study. The copper ores were obtained from sources located in northern Argentine.

\subsection{Methods}

The concentrate characterisation was carried out. The chemical composition of each sample was determined by acid attack and atomic absorption spectrometry using a Perkin Elmer AA110 instrument. The crystal phases were identified by X-ray diffraction (XRD) at room temperature using a Philips X'Pert diffractometer. The sulphide quantification was conducted by applying the ASTM standard C25 [13].

A microscopy study performed using an Olympus GX51 light microscope and applying a LECO IA32 analysis system, which allowed for the observation of the types of particles and their morphological characteristics.

Another objective of this paper was to evaluate the behaviour of the concentrates at high temperatures. To obtain information about the reactions that occur duringheating, melting tests were carried out at temperatures of up to $1300^{\circ} \mathrm{C}$ in air. Samples were melted in a porcelain crucible using an electric furnace. All of the melted samples were prepared for microscopy observation. Their structure was studied using light and scanning electron microscopy (SEM). Finally, the results were correlated with the DTA-TG results.

\section{Results}

\subsection{Chemical Composition}

The chemical composition of the five concentrates samples is presented in Table 1.

\subsection{Mineral Phases}

The X-ray diffraction results provide information regarding the crystalline phases present in the five samples studied. The major minerals present in the concentrates were chalcopyrite $\left(\mathrm{CuFeS}_{2}\right)$, pyrite $\left(\mathrm{Cu}_{2} \mathrm{~S}\right)$ and iron sulphide (FeS). Nevertheless, other minerals such as iron bisulphide $\left(\mathrm{FeS}_{2}\right)$, geerite $\left(\mathrm{Cu}_{8} \mathrm{~S}_{5}\right)$, enargite $\left(\mathrm{Cu}_{3} \mathrm{AsS}_{4}\right)$ and dicopper zinc silicon tetrasulphide $\left(\mathrm{Cu}_{2} \mathrm{Zn} \mathrm{SiS}_{4}\right)$, among others, were identified. However, sample E was observed to contain a lower chalcopyrite content and higher pyrite content. In sample $\mathrm{B}$, geerite $\left(\mathrm{Cu}_{8} \mathrm{~S}_{5}\right)$, enargite $\left(\mathrm{Cu}_{3} \mathrm{AsS}_{4}\right)$ and dicopper zinc silicon tetrasulphide $\left(\mathrm{Cu}_{2} \mathrm{Zn} \mathrm{SiS}\right)_{4}$ were identified, and in sample $\mathrm{C}, \mathrm{PbS}$ was identified. Traces of cassiterite $\left(\mathrm{SnO}_{2}\right)$ were identified in samples A and D. Figures 1-5 show the diffractograms of all of the samples, specifically the principal peaks corresponding to the crystal phases observed.

Table 1. Chemical composition of the copper concentrates samples.

(a)

\begin{tabular}{cccccccccc}
\hline Sample & $\mathbf{C u} \%$ & $\mathbf{F e} \%$ & $\mathbf{I n s} \%$ & $\mathbf{S i O}_{2} \%$ & $\mathbf{R}_{2} \mathbf{O}_{3} \%$ & $\mathbf{C a O} \%$ & $\mathbf{M g O} \%$ & $\mathbf{S}^{2}$ & $\mathbf{A l}_{2} \mathbf{O}_{3} \%$ \\
\hline A & 16.9 & 32.1 & 2.76 & 1.64 & 53.12 & 0.15 & 0.08 & 37.6 & 8.78 \\
B & 22.3 & 31.4 & 1.70 & 0.88 & 51.58 & 0.18 & 0.08 & 35.2 & 8.25 \\
C & 18.4 & 31.5 & 1.64 & 1.04 & 52.96 & 0.14 & 0.05 & 37.8 & 9.43 \\
D & 14.6 & 33.1 & 2.52 & 1.28 & 55.06 & 0.11 & 0.07 & 38.9 & 9.35 \\
E & 18.1 & 35.3 & 2.04 & 0.52 & 59.36 & 0.13 & 0.05 & 33.3 & 10.59 \\
\hline
\end{tabular}

(b)

\begin{tabular}{ccccc}
\hline Sample & Sb ppm & As ppm & Se ppm & $<50$ \\
A & $<50$ & 52 & $<30$ \\
B & $<50$ & 68 & $<50$ & $<50$ \\
C & $<50$ & 48 & $<50$ \\
D & $<50$ & 35 & $<30$ \\
E & $<50$ & 49 & $<50$ \\
\hline
\end{tabular}




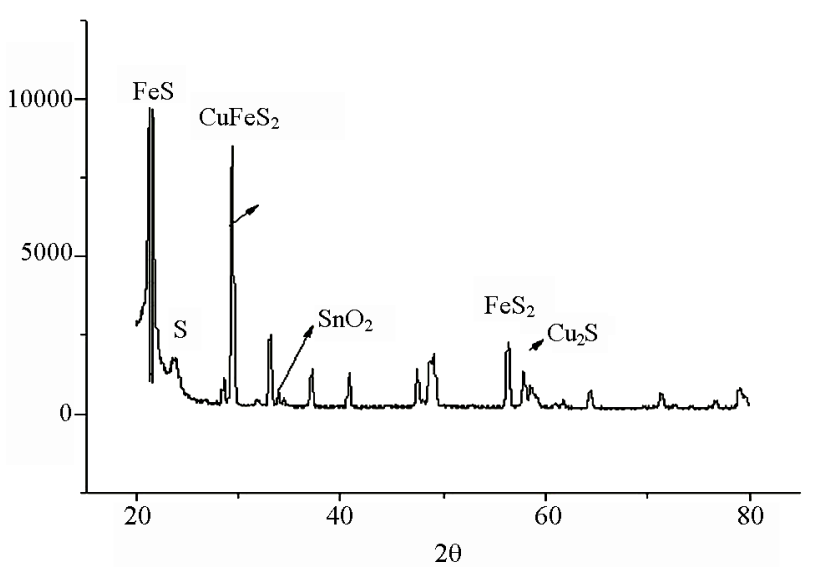

Figure 1. Sample A diffractogram.

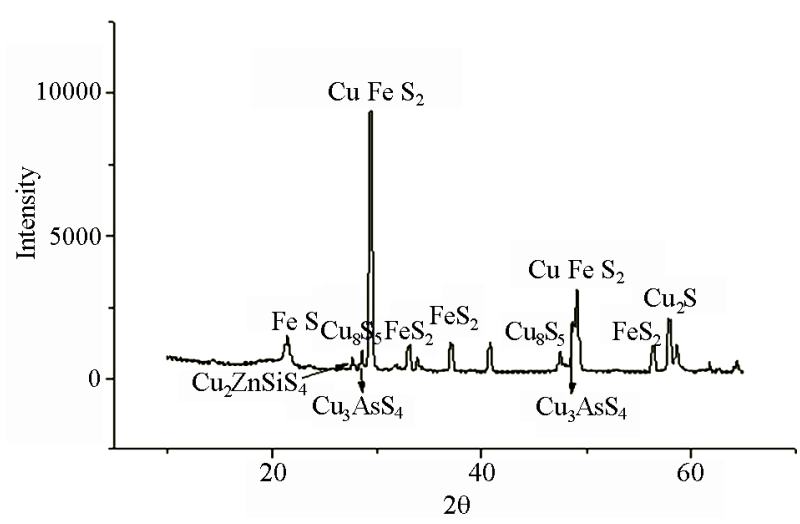

Figure 2. Sample B diffractogram.

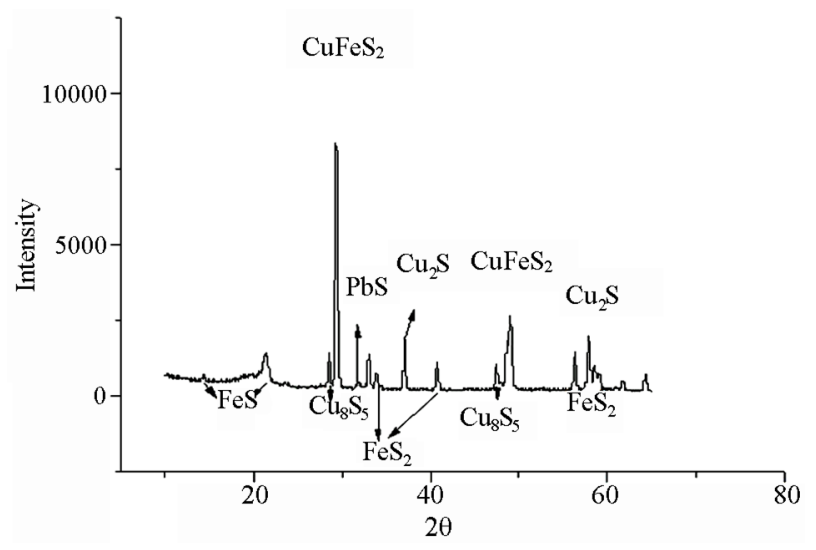

Figure 3. Sample C diffractogram.

\subsection{Thermal Analysis Tests}

DTA and TG tests were carried out at a heating rate of $10^{\circ} \mathrm{C} / \mathrm{s}$ using a JENCK instrument. In this manner, the mechanisms of oxidation during heating up to $1000^{\circ} \mathrm{C}$ were characterised for all of the copper concentrate samples. For each sample, the first exothermic peak temperature, $\mathrm{T}_{\mathrm{in}}$, was determined. This temperature establishes the beginning of the oxidisation reaction. The

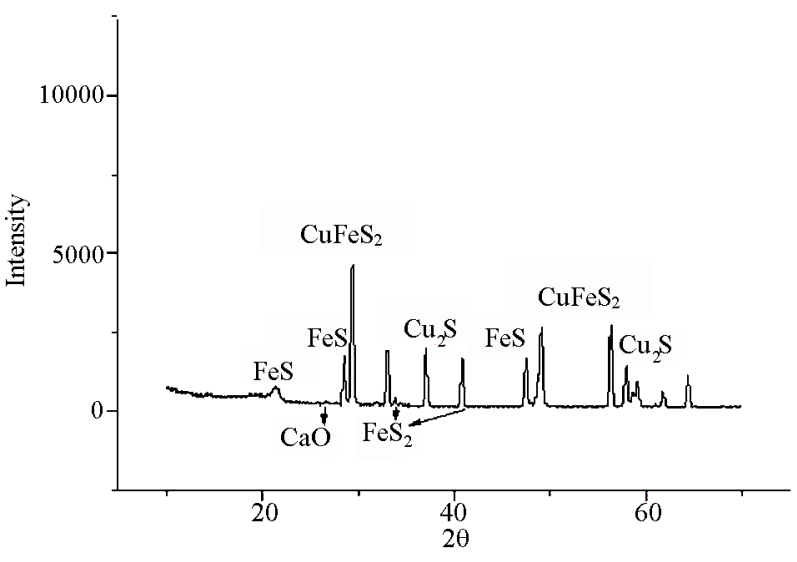

Figure 4. Sample D diffractogram.

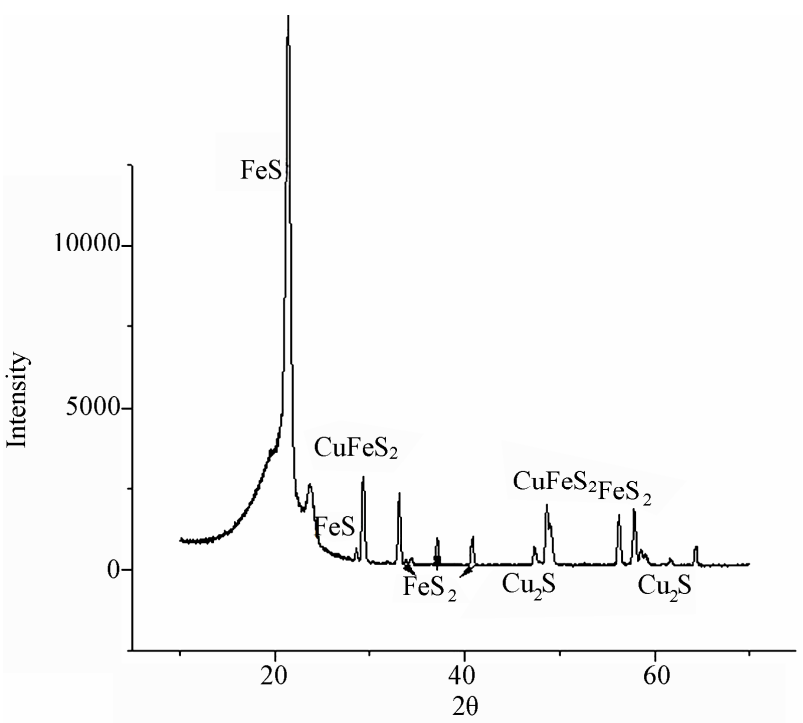

Figure 5. Sample E diffractogram.

exothermic heat, $\mathrm{Q}_{\mathrm{ex}}$, was determined by the area below the DTA curve. These values represent the total heat that developed during all of the reactions. Both values are very useful for understanding the flash-melting process $[11,12,14,15]$.

Figure 6 shows the DTA curves of the five samples. The $T_{\text {in }}$ and $Q_{e x}$ values calculated by numerical integration are presented in Table 2. Notably, both values are related to the oxygen content of the copper, which in this case, are constant.

The thermogravimetric curves (TG) (Figure 7) allow for the observation of mass changes and losses in the concentrate samples during heating.

\subsection{Melting Test}

Samples of each copper concentrate were melted in porcelain crucibles at $1200^{\circ} \mathrm{C}$ at a heating rate of $5^{\circ} \mathrm{C} / \mathrm{min}$ in air. The structure of the solidified product of each sample was studied by light and scanning electron microscopy 


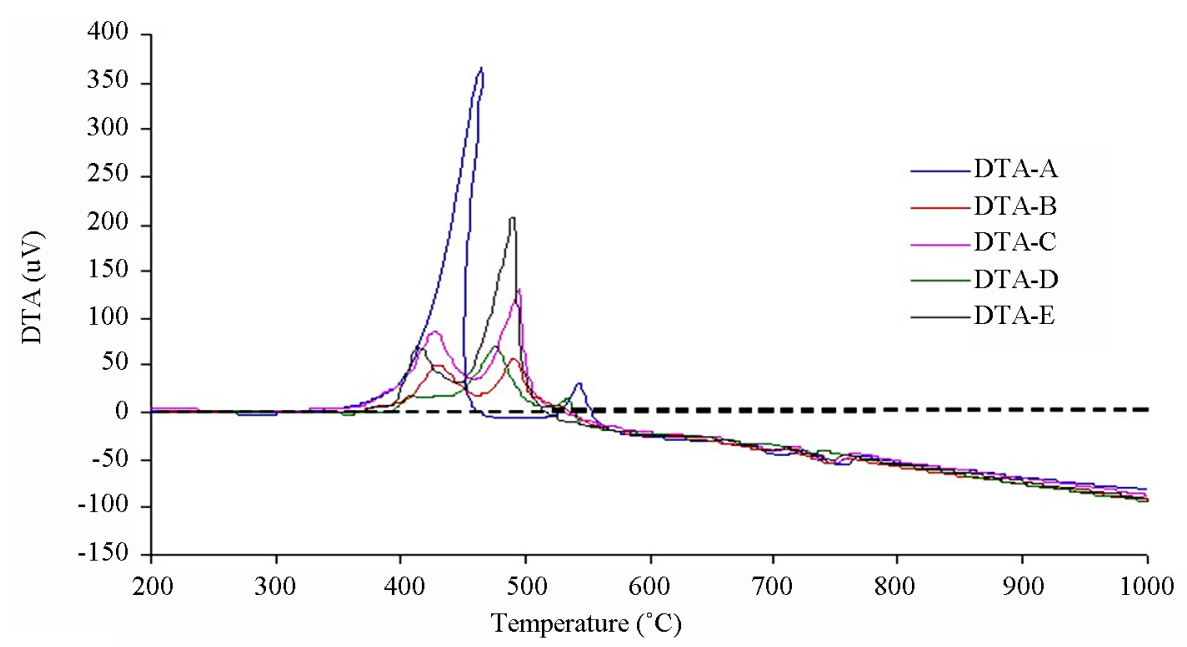

Figure 6. DTA curves of the five copper concentrates samples.

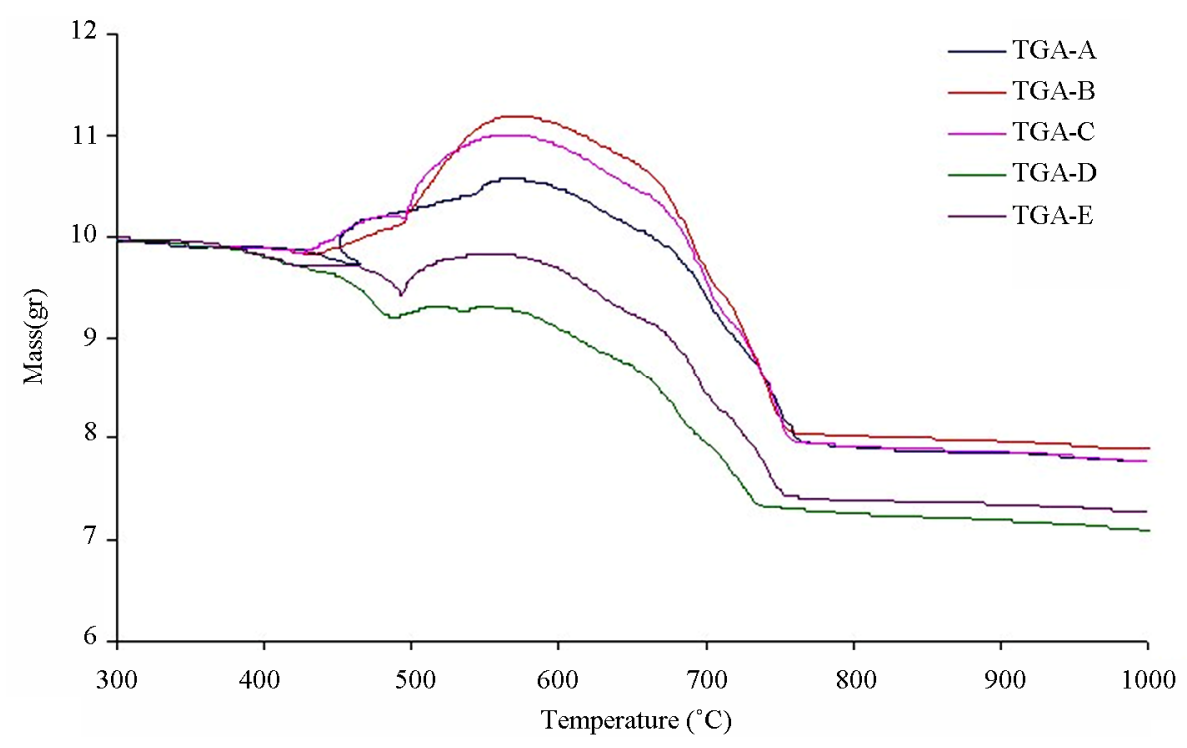

Figure 7. Thermogravimetric curves of the copper concentrates.

Table 2. Values of the initial oxidation temperature Tin, exothermic heat $Q_{e x}$ and the copper law of the concentrates.

\begin{tabular}{cccc}
\hline Sample & Copper law (\%) & $\mathbf{T}_{\text {in }}\left({ }^{\circ} \mathbf{C}\right)$ & $\mathbf{Q}_{\text {ex }}(\mathbf{K J} / \mathbf{K g})$ \\
\hline $\mathrm{A}$ & 16.86 & $309 \pm 10$ & $13880 \pm 300$ \\
$\mathrm{~B}$ & 22.28 & 344 & 5185 \\
$\mathrm{C}$ & 18.38 & 340 & 7328 \\
$\mathrm{D}$ & 14.65 & 390 & 3254 \\
$\mathrm{E}$ & 18.03 & 415 & 12225 \\
\hline
\end{tabular}

(SEM). In all cases, three different layers were recognised: a greyish layer with a fine dispersion of white particles (located in the bottom of the crucible), a white (intermediate) layer that contained a large number of dendritic crystals and extensive porosity and finally a top grey layer composed of spherical and irregular white particles of a larger size with respect to the bottom-layer particles. Figure 8 shows a vertical cross section of the solidified layers in sample A.

Notably, in the intermediate white layer, native copper bands (Figure 9) and white dendrites were observed. A higher proportion of native copper bands and globular particles was observed in sample B. In the grey top layer, white crystals with different morphologies, irregular, needle-shaped and dendritic, were observed.

In samples B, C, D and E, the bottom and top grey layers were observed to be thicker than those in sample $\mathrm{A}$ and to contain a low proportion of white particles. However, in all of the samples, the intermediate white layer was observed to contain metallic copper bands.

The phases were examined by SEM in the three layers. Elemental mapping revealed the elemental distribution in each layer. Table 3 shows the elemental distribution ob- 


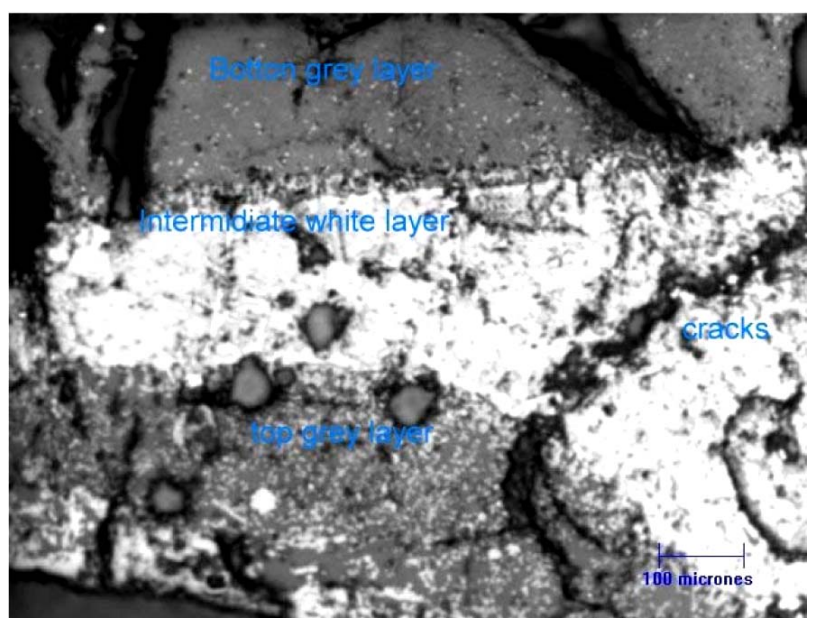

Figure 8. Three layers present in the structure of solidified product $A$.

served in sample A.

The bottom grey layer of the samples contains white particles of silicoaluminate. A few particles of $\mathrm{CuS}$ and phases with higher iron contents were observed near the interface in contact with the intermediate white layer. Also, traces of other elements such as $\mathrm{Mg}$ and $\mathrm{Cr}$ in the silicoaluminate matrix were detected.

The intermediate white layer contains metallic copper bands, white dendrites or irregular crystals of $(\mathrm{Cu}, \mathrm{Fe}) \mathrm{S}$, and the matrix has a high iron sulphide ( $\mathrm{FeS})$ content.

The white and the grey top layers were observed to be porous. Sample D showed the highest porosity among the samples studied.

The top grey layer matrix consists of calcium silicoaluminate and copper sulphide particles (with dendritic and globular morphologies). Traces of $\mathrm{K}, \mathrm{Ti}$ and $\mathrm{Cr}$ were identified. Irregular copper particles isolated in the layer and in the microcracks were also observed.

If we consider copper, iron and sulphur to be the main elements and approximate their content to be $100 \%$, it is possible to plot on a ternary diagram the sulphide composition identified in the intermediate white layer and in the grey top layer. For simplicity, the plotted compositions correspond to samples A and D (Figure 10).

These two samples were selected because of the phases differences observed. Samples B, C and E contain phases similar to those observed in sample A but in different proportions. Notably, the sulphide phases developed under the test conditions $\left(1200^{\circ} \mathrm{C}\right)$ show copper contents up to $52 \%$.

\section{Discussion}

The chemical composition of the concentrates show that sample B possessed a higher $\mathrm{Cu}$ content $(22.28 \%)$ and a lower content of $\mathrm{Fe}(31.40 \%)$. Importantly, sample B also exhibited the lowest $\mathrm{S} / \mathrm{Cu}$ ratio $(1,58)$.

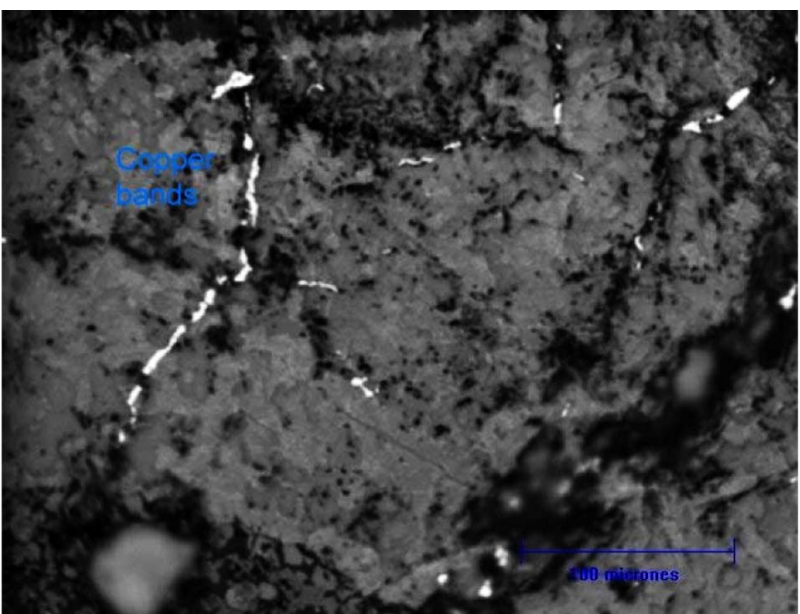

Figure 9. Copper band observed in the intermediate.

Sample D contained the lowest concentration of $\mathrm{Cu}$ $(14.65 \%)$ and the highest $\mathrm{S}$ and $\mathrm{Fe}$ concentrations. Moreover, the $\mathrm{S} / \mathrm{Cu}$ ratio of sample $\mathrm{D}$ was 2.65 , which is highest value observed in the concentrate samples. The XRD results are consistent with the chemical composition results.

Based on the DTA results, the correlation between the $T_{i n}$ and $Q_{e x}$ values with respect to the law of copper concentration $(\mathrm{Cu}(\mathrm{X}))$ can be modelled by third-degree polynomial equations, (Equations (1) and (2)) for which $\mathrm{R}=0.9946$.

$$
\begin{aligned}
\mathrm{T}_{\text {in }}\left({ }^{\circ} \mathrm{C}\right)= & 1.425(\mathrm{X})^{3}-78.488(\mathrm{X})^{2} \\
& +1377.8(\mathrm{X})-7490.8 \\
\mathrm{Q}_{\text {ex }}(\mathrm{KJ} / \mathrm{Kg}) & =-215.6(\mathrm{X})^{3}+14335(\mathrm{X})^{2} \\
& -268157(\mathrm{X})+2 \cdot \mathrm{E}^{+6}
\end{aligned}
$$

The $T_{\text {in }}$ values vary with mineralogical composition and respect the following order of the samples: $A<C<$ $\mathrm{B}<\mathrm{D}<$ E. As observed experimentally, sample $\mathrm{B}$ has an intermediate initial oxidation temperature. A higher content of pyrite indicates an increase in $T_{\text {in }}$ because of the high melting temperature of the compound. Nevertheless, the other phases in the concentrates also affect $T_{\text {in }}$.

The exothermic heat $Q_{e x}$ values were obtained by the numerical integration of the exothermic peaks on the DTA curves (Figure 6). The exothermic heat is generally associated with the oxygen content present during the test. However, in this case, the oxygen concentration is constant. Thus, it is possible that the higher value is due to the chalcopyrite $\left(\mathrm{CuFeS}_{2}\right)$ and coveline $(\mathrm{CuS})$ contents.

The DTA and TG curves show that the sample-B reactions develop with low $\mathrm{Q}_{\mathrm{ex}}$, which is associated with a significant loss of mass during heating between room temperature and $1000^{\circ} \mathrm{C}$. A gradual weight loss in the 
Table 3. Element distribution in the three layers of the post melted sample A.

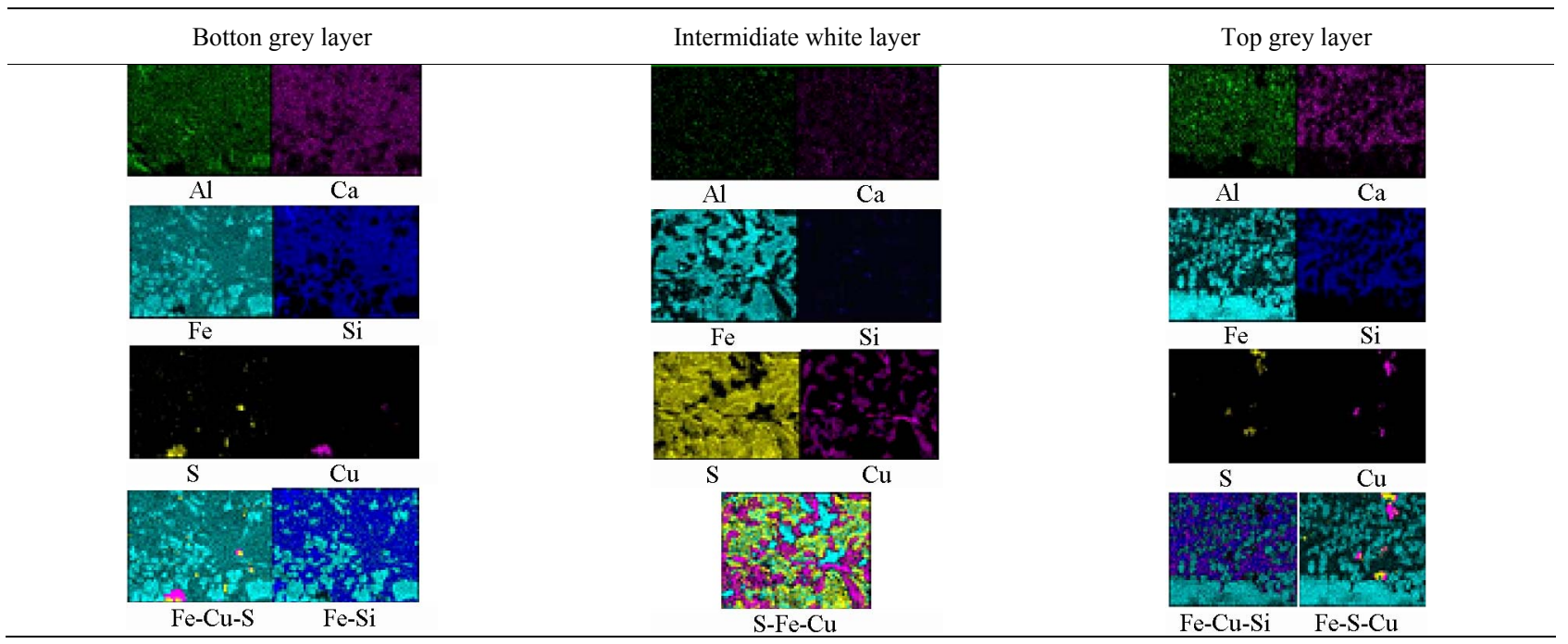

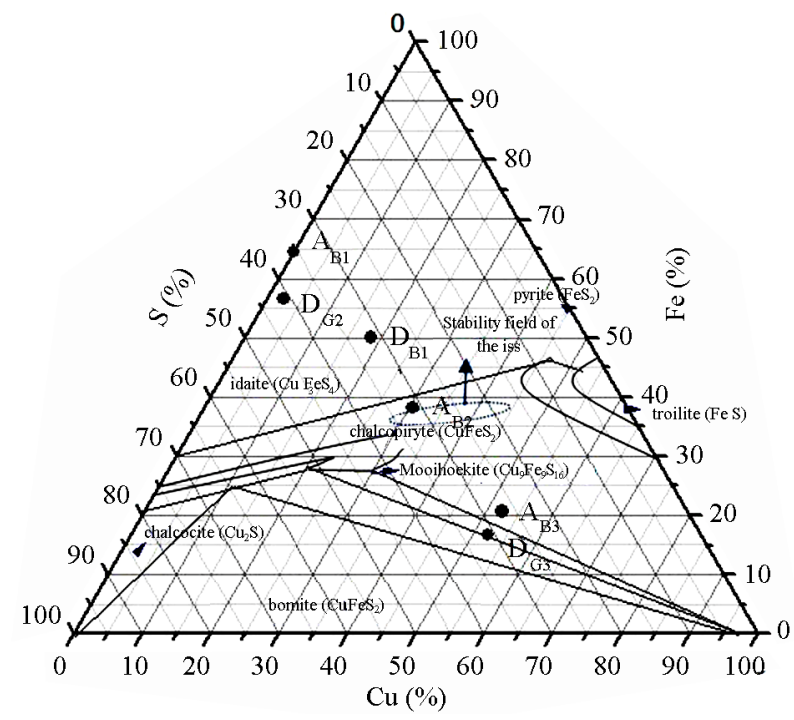

Figure 10. Sulphide composition determined in the white (в) intermediate layer and in the grey ${ }_{G}$ ) top layer of samples $A$ and $D$.

range of $300^{\circ} \mathrm{C}$ to $450^{\circ} \mathrm{C}$ was observed for all of the concentrates. This change is attributed to humidity loss. In particular, sample E exhibited a drastic loss of mass at $500^{\circ} \mathrm{C}$; this is because the range $450^{\circ} \mathrm{C}-550^{\circ} \mathrm{C}$ favours the direct oxidation of pyre to loadstone, while at temperatures above $650^{\circ} \mathrm{C}$ the complete elimination of any formed ferrous sulphate is favoured; this is manifested as weight loss [16].

A gradual increase in mass up to $600^{\circ} \mathrm{C}$ was observed for all of the concentrate samples. The transformation of the sulphides into oxides coincides with these masschange exothermic peaks (in DTA curves). A new and pronounced loss of mass up to $750^{\circ} \mathrm{C}$ was observed for the five concentrates. At these temperatures, the trans- formations are probably associated with the sulphide and $\mathrm{SO}_{2}$ dissociation.

The proposed reaction mechanisms, based on the behaviour indicated by the DTA and TG curves and the equilibrium information obtained by calculation using the software program HSC (Outokumpu), are detailed in Table 4.

The DTA results are consistent with proposed reaction 5 , which implies a loss of mass because of the sulphide-to-oxide transformation. In addition, it is important to consider the chalcopyrite $\left(\mathrm{CuFeS}_{2}\right)$ transformation (reactions 3 and 4).

The initial mass loss revealed by TG is based on the decomposition of a pure $\mathrm{Cu}_{2} \mathrm{~S}$ sample and the oxidation of pyrite, as observed in reactions 5 and 6 .

The gradual increase in mass determined by the TG test at $600^{\circ} \mathrm{C}$ was also reported by Perez-Tello et al. [17]. They believed that the concentrates quickly gain mass through the copper sulphate formation. However, Figure 11 shows that reactions 11 and 10 contribute to the increase in mass through the formation of iron sulphide. Although this species is later dissociated, as indicated by reaction 14 , the reaction speed is slow due to that the formation of sulphates, which closes the pores of the particle and prevents the reaction from occurring, and thus creates a gain in mass, as shown in Figure 7 [16].

The gradual final loss of mass is explained by the decomposition reactions of the sulphate into oxides.

Samples B and C showed the same behaviour during heating because of their similar mineralogical composition: high content of chalcopyrite $\left(\mathrm{CuFeS}_{2}\right)$ and low copper and iron sulphides in the concentrate. These samples developed intermediate $\mathrm{T}_{\text {in }}$ and $\mathrm{Q}_{\mathrm{ex}}$ during heating.

Sample A presented a lower $\mathrm{T}_{\text {in }}$ and higher $\mathrm{Q}_{\mathrm{ex}}$ because of the higher contents of chalcopyrite $\left(\mathrm{CuFeS}_{2}\right)$ 
Table 4. Reaction mechanisms.

\begin{tabular}{|c|c|c|c|}
\hline Reaction & $-\Delta G^{\circ}(\mathbf{k c a l})_{\text {reacc }}$ & Mass changes $\%$ & Reaction number \\
\hline $5 \mathrm{CuFeS}_{2}+9 \mathrm{O}_{2}(\mathrm{~g})=\mathrm{Cu}_{5} \mathrm{FeS}_{4}+2 \mathrm{Fe}_{2} \mathrm{O}_{3}+6 \mathrm{SO}_{2}(\mathrm{~g})$ & $653-621$ & -10.50 & 1 \\
\hline $2 \mathrm{Cu}_{5} \mathrm{FeS}_{4}+14.5 \mathrm{O}_{2}(\mathrm{~g})=10 \mathrm{CuO}+\mathrm{Fe}_{2} \mathrm{O}_{3}+8 \mathrm{SO}_{2}(\mathrm{~g})$ & $876-788$ & -4.85 & 2 \\
\hline $2 \mathrm{CuFeS}_{2}+6.5 \mathrm{O}_{2}(\mathrm{~g})=2 \mathrm{CuO}+\mathrm{Fe}_{2} \mathrm{O}_{3}+4 \mathrm{SO}_{2}(\mathrm{~g})$ & $436-406$ & -8.59 & 3 \\
\hline $2 \mathrm{CuFeS}_{2}+6 \mathrm{O}_{2}(\mathrm{~g})=\mathrm{Cu}_{2} \mathrm{O}+\mathrm{Fe}_{2} \mathrm{O}_{3}+4 \mathrm{SO}_{2}(\mathrm{~g})$ & $410-387$ & -17.50 & 4 \\
\hline $2 \mathrm{FeS}_{2}+5.5 \mathrm{O}_{2}(\mathrm{~g})=\mathrm{Fe}_{2} \mathrm{O}_{3}+4 \mathrm{SO}_{2}(\mathrm{~g})$ & $388-377$ & -33.44 & 5 \\
\hline $2 \mathrm{FeS}+3.5 \mathrm{O}_{2}(\mathrm{~g})=\mathrm{Fe}_{2} \mathrm{O}_{3}+2 \mathrm{SO}_{2}(\mathrm{~g})$ & $273-253$ & -9.17 & 6 \\
\hline $\mathrm{Cu}_{2} \mathrm{~S}+2 \mathrm{O}_{2}(\mathrm{~g})=2 \mathrm{CuO}+\mathrm{SO}_{2}(\mathrm{~g})$ & $113-98$ & -0.04 & 7 \\
\hline $\mathrm{Cu}_{2} \mathrm{~S}+1.5 \mathrm{O}_{2}(\mathrm{~g})=\mathrm{Cu}_{2} \mathrm{O}+\mathrm{SO}_{2}(\mathrm{~g})$ & $86-79$ & -10.09 & 8 \\
\hline $2 \mathrm{Cu}_{5} \mathrm{FeS}_{4}+2 \mathrm{SO}_{2}(\mathrm{~g})+19.5 \mathrm{O}_{2}(\mathrm{~g})=10 \mathrm{CuSO}_{4}+\mathrm{Fe}_{2} \mathrm{O}_{3}$ & $1066-781$ & 74.91 & 9 \\
\hline $2 \mathrm{CuFeS}_{2}+9 \mathrm{O}_{2}(\mathrm{~g})+\mathrm{SO}_{2}(\mathrm{~g})=2 \mathrm{CuSO}_{4}+\mathrm{Fe}_{2}\left(\mathrm{SO}_{4}\right)_{3}$ & $532-403$ & 95.92 & 10 \\
\hline $\mathrm{FeS}_{2}+3 \mathrm{O}_{2}(\mathrm{~g})=\mathrm{FeSO}_{4}+\mathrm{SO}_{2}(\mathrm{~g})$ & $203-176$ & 233.33 & 11 \\
\hline $\mathrm{Cu}_{2} \mathrm{~S}+2.5 \mathrm{O}_{2}(\mathrm{~g})=\mathrm{CuO} * \mathrm{CuSO} 4$ & $125-90.61$ & 50.26 & 12 \\
\hline $2 \mathrm{Cu}_{2} \mathrm{O}+\mathrm{O}_{2}(\mathrm{~g})=4 \mathrm{CuO}$ & $14-5$ & 11.17 & 13 \\
\hline $2 \mathrm{FeSO}_{4}+1.5 \mathrm{O}_{2}(\mathrm{~g})=\mathrm{Fe}_{2} \mathrm{O}_{3}+2 \mathrm{SO}_{2}(\mathrm{~g})+2 \mathrm{O}_{2}(\mathrm{~g})$ & $6-26$ & -47.44 & 14 \\
\hline $\mathrm{Fe}_{2}(\mathrm{SO} 4)_{3}=\mathrm{Fe}_{2} \mathrm{O}_{3}+3 \mathrm{SO}_{2}(\mathrm{~g})+1.5 \mathrm{O}_{2}(\mathrm{~g})$ & $3-41$ & -60.06 & 15 \\
\hline $2 \mathrm{CuSO}_{4}+\mathrm{O}_{2}(\mathrm{~g})=2 \mathrm{CuO}+2 \mathrm{SO}_{2}(\mathrm{~g})+2 \mathrm{O}_{2}(\mathrm{~g})$ & $+10-14$ & -50.16 & 16 \\
\hline $2 \mathrm{CuO} * \mathrm{CuSO}_{4}=4 \mathrm{CuO}+2 \mathrm{SO}_{2}(\mathrm{~g})+\mathrm{O}_{2}(\mathrm{~g})$ & $+13-10$ & -33.48 & 17 \\
\hline
\end{tabular}

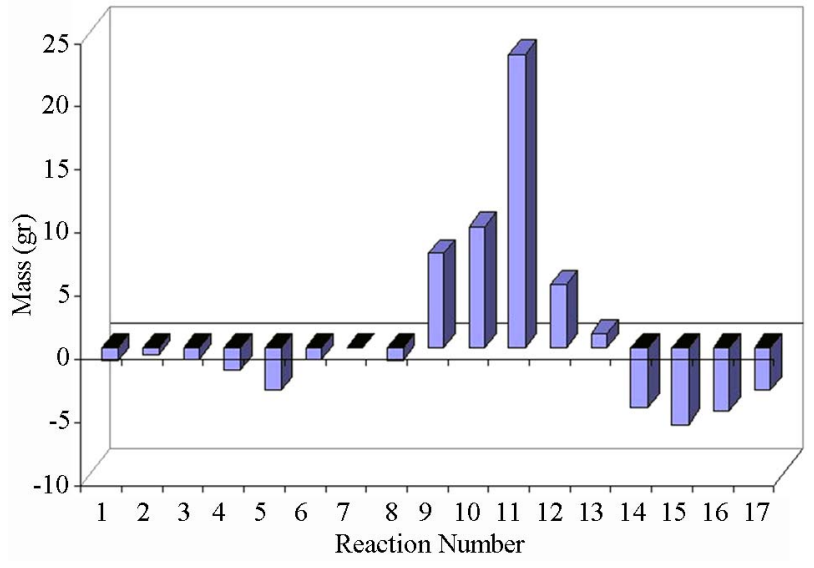

Figure 11. Mass evolution with respect to reaction mechanisms.

and iron sulphide (FeS), promoting an intermediate change in weight.

Sample E, which contained the highest percentage of FeS, showed a combination of higher $\mathrm{Q}_{\mathrm{ex}}$ and $\mathrm{T}_{\mathrm{in}}$. The mass lost by this sample is lower than that by samples $\mathrm{A}$, $\mathrm{B}$ and $\mathrm{C}$.

The microscopy study of the five concentrates solidified samples showed that the contents of chalcopyrite and iron sulphide (i.e., sample A) in the concentrates increase with the thickness of the white layer. In all samples, this white intermediate layer featured native copper bands or globular particles because of the decomposition of sulphides. In this case, the $(\mathrm{Cu}, \mathrm{Fe}) \mathrm{S}$ exhibited $31 \%$
$\mathrm{Cu}$.

In the top grey layer matrix, white dendrites or irregular crystals of $(\mathrm{Cu}, \mathrm{Fe}) \mathrm{S}$ in a matrix with a higher iron sulphide (FeS) content were identified. These phases were observed in the greatest quantity in samples D and E. $(\mathrm{Cu}, \mathrm{Fe}) \mathrm{S}$ contained approximately $52 \% \mathrm{Cu}$.

Based on the S-Cu-Fe system, it was possible to conclude that different sulphide phases formed at the selected melting test conditions $\left(1200^{\circ} \mathrm{C}, 1 \mathrm{~h}\right)$ in both layers $\left(A_{B}\right.$ or $D_{B}$ in the white intermediate layer and $A_{G}$ or $\mathrm{D}_{\mathrm{G}}$ of the grey top layer) contain up to $52 \%$ copper. Chalcopyrite decomposes at $623 \mathrm{~K}$ to an intermediate solid solution (ISS) (see Figure 10) or to chalcopyrite with a slightly different composition $\left(\mathrm{CuFeS}_{2 \mathrm{ssb}}\right)$; moreover, an iron sulphide transformation occurred. The presence of native copper in all of the samples indicates that sulphur was only partly removed.

\section{Conclusions}

To summarise, the characterisation of the five concentrates studied in this work revealed that these materials contained about $14 \%$ to $22 \%$ copper and that sample B was the richest in copper. The major copper minerals were sulphides: chalcopyrite $\left(\mathrm{CuFeS}_{2}\right)$ and coveline $(\mathrm{CuS})$. Iron was present in the concentrates in the form of $\mathrm{FeS}_{2}$ or FeS. Samples A and E showed the highest iron sulphide contents

The thermal analysis techniques applied in this study provided information that allowed us to determine the 
initial oxidation temperature $T_{\text {in }}$ and the exothermic heat $\mathrm{Q}_{\mathrm{ex}}$ of the samples, as well as the mass changes during heating to $1000^{\circ} \mathrm{C}$.

By correlating the DTA and TG results with the crystal phases identified by XRD and the information obtained though the thermodynamic equilibrium study performed using the software program HSC (Outokumpu), it was possible to identify the complex reaction mechanisms involved during concentrate heating. The reaction evolution features an initial transformation of the sulphides to oxides; then, the oxides react to form sulphates and are finally transformed to oxides. These results were confirmed by the phases identified by microscopy and the thermodynamic study on the $\mathrm{Cu}-\mathrm{Fe}-\mathrm{S}$ system.

\section{REFERENCES}

[1] "Peralta e. Actas de Encuentro Internacional de Minería," Secretaria de Minería de la Nación. Buenos Aires, Argentina, 1994, pp. 5-15.

[2] Segemar, Servicio Geológico Minero de Argentina. http://www.segemar.gov.ar/P_Oferta_Regiones/Oferta/Int roducción.htm

[3] A. Beretta and V. Bazan, "Algunos Fundamentos de las Ventajas Estratégicas de la Instalación de una Fundición de Cobre en Argentina," SAM/CONAMET, San Nicolás, Buenos Aires, 2007, pp. 7-12.

[4] A. Guitierrez, D. Chong and R Espinoza, "Niveles de Exposición de Yacimientos del Distrito Minero de agua de Dionisio (YMAD)," Revista de la Asociación Geológica Argentina, Catamarca, Vol. 61, No. 2, 2006, pp. 269-277.

[5] V Bazan, P Sarquis and E. Brandaleze, "Caracterización de un Mineral de Cobre en Argentina para la Producción de Matte," Revista Dyna, No. 167, 2011, pp. 220-228.

[6] V. Bazán, P. Sarquis and E. Brandaleze, "Factibilidad de una Industria Pirometalurgia con Mineral Argentino 1ras," Jornadas de Investigación de la Minería del norte Argentino Editorial Científica Universitaria, Universidad Nacional de Catamarca, 2009.

[7] J. Dunn and C. Muzenda, "Thermal oxidation of covellite (CuS)," Thermochimica Acta, Vol. 369, No. 1-2, 2001, pp. 117-123. http://dx.doi.org/10.1016/S0040-6031(00)00748-6
[8] L. Winkel, I. Alxneit and M. Sturzenegger, "Thermal Decomposition of Copper Concentrates under Concentrated Radiation-Mechanistic Aspects of the Separation of Copper from Iron Sulfide Phases," International Journal of Mineral Processing, Vol. 88, No. 1-2, 2008, pp. 24-30. http://dx.doi.org/10.1016/S0040-6031(00)00748-6

[9] H. Tsukada, Z. Asaki, T. Tanabe and Y. Kondo, "Oxidation of Mixed Copper-Iron Sulfide," Metallurgical Transactions B-Process Metallurgy, Vol. 12, No. 3, 1981, pp. 603-609. http://dx.doi.org/10.1007/BF02654333

[10] M. Perez-Tello, H. Y. Sohn and J. Lottiger, "Determination of the Oxidation Characteristics of Solid Copper Matte Particles by Differential Scanning Calorimetry and Thermogravimetric Analysis," Minerals \& Metallurgical Processing, Vol. 16, No. 2, 1999, pp. 1-7.

[11] J. Dunn and S. Jayaweera, "Applications of Thermoanalytical Methods to Studies of Flash Smelting Reactions," Thermochimica Acta, Vol. 85, 1985, pp. 115-118. http://dx.doi.org/10.1016/0040-6031(85)85543-X

[12] Z. Zivkovic, N. Strbac, D. Zivkovic, V. Velinovski and I. Mihajlovic, "Kinetic Study and Mechanism of Chalcocite and Covellite Oxidation Process," Journal of Thermal Analysis and Calorimetry, Vol. 79, No. 3, 2005, pp. 715720. http://dx.doi.org/10.1007/s10973-005-0601-1

[13] ASTM C25-99, "Stándar Test Methods for Chemical Analysis of Limestone, Quicklime and Hydrated Lime," 1999.

[14] F. Jorgensen and P. Koh, "Combustion in Flash Smelting Furnaces,” JOM, Vol. 53, No. 5, 2001, pp. 16-21. http://dx.doi.org/10.1007/s11837-001-0201-x

[15] S. Perez-Fontes, "Determinación de las Características de Oxidación de Minerales Sulfurosos a Altas Temperaturas," Tesis de Licenciatura en Ingeniería Química, Universidad de Sonora, Hermosillo Sonora, 2004.

[16] V. Arias, R. Coronado, L. Puente and D. Lovera, "Refractariedad de Concentrados Auriferous," Revista del Instituto de Investigación de la Facultad de Ingeniería Geológica, Minera, Metalúrgica y Geográfica, Vol. 8, No. 16, 2005, pp. 5-14.

[17] S. Perez-Fontes, M. Perez-Tello, L. Prieto, F. Brown and F. Castillon-Barraza, "Thermoanalytical Study on the Oxidation of Sulfide Minerals at High Temperatures," Minerals \& Metallurgical Processing, Vol. 24, No. 4, 2007, pp. 275-283. 